\title{
Assessment of the validity of Immunofluorescent antibody test method
}

\section{İmmün floresan antikor testlerinin yöntem geçerliliğinin değerlendirilmesi}

\author{
Cemile SÖNMEZ1', Yavuz DOĞAN², Tülin DEMiR¹, Aydan ÖZKÜTÜU²
}

\section{ABSTRACT}

Objective: Assessment of the validity of a method including TS EN ISO 17025 and TS EN ISO 15189, is a formal requirement of accreditation standards. Before routine testing, validity of every test should be assessed in accordance with internationally accepted criteria. Validation / verification requirements varies according to the criteria that a test is CE/FDA approved or is an in-house test, or gives qualitative or quantitative results. While verification is adequate for CE approved tests, validation is necessary for inhouse tests.

Methods: In this study, it was evaluated the validity of commercial CE approved tests, such as anti-nuclear antibody IgG IFAT, anti-endomysium IgA IFAT anti-gliadin IgA IFAT. Accuracy and reproductibility of the tests (intraassay, inter-assay) are performed for the verification of the tests and samples from an accredited laboratory are used.

Results: CE approved commercial anti-nuclear antibody IgG IFAT, anti-endomysium IgA IFAT, anti-gliadin IgA IFAT with $100 \%$ accuracy and precision are considered as valid in our laboratory conditions.

Conclusion: As a result the method used in our study for the validity of the qualitative serological tests is found to be applicable and use of a test sample from an accredited institution as a control material were

\section{ÖZET}

Amaç: Yöntem geçerliliğinin değerlendirilmesi TS EN ISO 17025 ve TSE EN ISO 15189 akreditasyon standartlarının resmi bir gerekliliğidir. Testlerin rutin uygulamaya geçmeden önce uluslararası kabul görmüș kriterler doğrultusunda geçerliliği değerlendirilmelidir. Testin CE/FDA onaylı olması veya laboratuvar yapımı olmasına ve kalitatif veya kantitatif sonuç vermesine bağlı olarak validasyon/verifikasyon gereklilikleri değișmektedir. CE onaylı bir test için verifikasyon yeterli olurken, laboratuvar tarafından geliștirilen bir testin tüm validasyon çalıșmalarının yapılması gereklidir.

Yöntem: Bu çalıșmada CE onaylı olan anti-nükleer antikor IgG IFAT, anti-endomisyum IgA IFAT, antigliadin IgA IFAT ticari testlerinde yöntem geçerliliği değerlendirilmiștir. Çalıșmada testlerin laboratuvar içi geçerliliğinin değerlendirilmesi için doğruluk ve tekrarlanabilirlik testleri çalıșılmıș ve test materyali olarak akredite bir kurulușa ait örnekler kullanılmıștır.

Bulgular: FCE onaylı anti-nükleer antikor IgG IFAT, anti-endomisyum IgA IFAT, anti-gliadin IgA IFAT ticari testleri \%100 doğruluk ve kesinlik ile laboratuvarımız koșullarında geçerli olarak değerlendirilmiștir.

Sonuç: Sonuç olarak kalitatif serolojik testlerin yöntem geçerliliğinin değerlendirilmesinde, kullanılan yöntemin uygulanabilir olduğu ve sertifikalı materyal temininde zorlanıldığı durumlarda kontrol materyali

'Public Health Institution of Turkey, Microbiology Reference Laboratories, Ankara

${ }^{2}$ Dokuz Eylül University Medical School, Microbiology Department, İzmir

DOI ID : 10.5505/TurkHijyen.2017.98159

Sönmez C, Doğan Y, Demir T, Özkütük A. Assessment of the validity of Immunofluorescent antibody test method.

Turk Hij Den Biyol Derg, 2017; 74(4): 333-340 
considered to be practical in cases where it is difficult to obtain certified material.

Key Words: Verification, accuracy, precision, qualitative test, IFAT

\section{INTRODUCTION}

Medical laboratories have the responsibility to provide timely and accurate test results. Nowadays, accreditation of the medical laboratories has become a necessity beyond recommendation in most countries (1). Assessment of the validity of a method including TS EN ISO 17025 and TS EN ISO 15189, is a formal requirement of accreditation standards. Before routine testing, validity of every test should be assessed in accordance with internationally accepted criteria (2). Validation / verification requirements varies according to the criteria that a test is CE/FDA approved or is an inhouse test, or gives qualitative or quantitative results. While verification is adequate for CE approved tests, validation is necessary for in-house tests. Accuracy, intraassay and inter-assay precision (reproducibility) and also linearity for quantitative tests are recommended in the verification of commercial serological tests which are CE/FDA approved (3). Certified reference material, external quality control samples or patient samples tested previously in an accreditated laboratory for the relevant tests could be used as control material in the studies. Verification of the test should be repeated in case of any change in equipment, test procedure, sample species and person who is performing the test (4).

In this study the validity of commercial CE approved tests, such as anti-nuclear antibody lgG IFAT, anti-endomysium IgA IFAT, anti-gliadin IgA IFAT were evaluated. Accuracy and precision tests (intra-assay, inter-assay) are performed for the verification of the tests.

\section{MATERIAL and METHOD}

CE-certificated anti-nuclear antibody (ANA) IgG (Euroimmun, Germany), anti-endomysium IgA (Euroimmun, Germany), anti-gliadin IgAIFAT (Euroimmun, olarak ilgili testlerde akredite bir kuruma ait örneklerin kullanılmasının pratik bir yöntem olduğu düșünülmüștür.

Anahtar Kelimeler: Verifikasyon, doğruluk, tekrarlanabilirlik, kalitatif test, IFAT

Germany) tests were included in the verification study which is conducted in Public Health Institution of Turkey, Microbiology Reference Laboratories in Ankara, Turkey. Sera samples of Immunology Department of Dokuz Eylul University (DEU) Hospital in Izmir which is accreditated for ANA IgG, anti-endomysium and anti-gliadin IgA IFAT used as reference material. Samples were transported in cold chain to laboratory and stored at $-20^{\circ} \mathrm{C}$ until testing.

IFAT (Mosaic Hep-20-10/Liver (Monkey)) was performed to determine IgG antibodies against antinuclear antibodies (ANA) in human sera. The principle of the test is based on antigen-antibody reaction and kits are consisted of slides coated with Hep2 and monkey liver cells. IFAT (Liver (primate) / Gliadin (GAF-3X) (IgA)) was used to detect IgA type antibodies against endomysium (EmA) and gliadin (GAF-3X) in human sera. Similar with the ANA IFAT, test principle is based on antigen-antibody reaction and consisted of slides coated with primate liver and trimer of a deamidated gliadin analogue fusion peptide (GAF-3X). Tests were performed according to the manufacturer's instructions. Positive and negative control samples provided from the manufacturer were used in each test. Patient samples are diluted 1:100 in PBS Tween for ANA IgG and 1:10 for anti- gliadin IgA and anti-endomysium IgA tests. Results of the patient sera were evaluated qualitatively in case of accepted positive and negative control testing results. Criteria recommended by Rabenau et al. (3) for CE/FDA-approved qualitative test kits was used in the verification study. In this context, accuracy and precision (intra-assay, inter-assay) studies were performed for the verification of the qualitative ANA IgG, anti-endomysium IgA and anti-gliadin IgA IFAT tests. Positive, low positive and negative samples were used for the verification study. Low-positive samples were obtained by the dilution of positive samples 1: 100 in accordance with 
the recommendations given in the kit prospectus.

Nine serum sample were used in the accuracy study. In each batch, three positive (rough granular, nuclear dots and homogen patterns), three low positive and three negative sample were used. Accuracy value of the test was calculated according to the formula "number of compatible test results/total number of results $x$ 100".

Precision is the scale of reproducibility in the testing condition and could be determined by performing different analysis of inter-assay and intra-assay studies. It is performed with one positive and one low positive samples. For intra-assay precision, in the same day in the same study one positive and one low positive samples is performed three times. For inter-assay precision one positive and one low positive samples are tested in the same study once a day, 3 days respectively as recommended by Rabenau et al (3). Reproducibility test results is calculated by the formula "number of compatible results/total number of resultsx100".

\section{RESULTS}

Evaluation of the method validation of ANA IgG, antiendomysium IgA and anti-gliadin IgA IFAT tests in our laboratory revealed that accuracy, inter-assay and intraassay reproducibility rates showed $100 \%$ accordance with the results of DEU Laboratories. Results were shown on Table I-VI and Figure 1-6.

\section{DISCUSSION}

Anti-nuclear antibody testing is used as an aid in the diagnosis of systemic rheumatic diseases in conjunction with other laboratory and clinical findings. Anti-gliadin antibody (AGA), anti-tissue transglutaminase antibody (anti-dTG) and/or anti-endomysium antibody (EMA) screening is used as a first diagnostic tool for Celiac disease and is recommended prior to ileal biopsy. Indirect fluorescent antibody test (IFAT) is the common standard method for the detection of these antibodies (5). According to the American College of Rheumatology 2011 data, IFAT method was approved as the gold standard method in the detection of ANA. Additionally, equivalent test results achieved by other methods with IFAT should be confirmed according to the relevant data (6). The main advantages of IFAT method is that it is a cost effective and easy method to perform and also it is available to evaluate the pattern along with ANA positivity in the detection of anti-nuclear antibody supporting the laboratory diagnosis. As the interpretation of the tests are evaluated visually, the reliability of the results depends on the knowledge and experience of the person and yield to have disconcordant results between laboratories (5).

According to quality management systems and international accreditation standards, confirmation of the method validation should be performed prior to routine testing in the medical laboratories. While verification is enough for CE-approved tests, all validation studies should be performed for the tests developed in-house. Compatibility of a test does not mean that the test was performed correctly always or give valid results. 98/79/EC IVD Directive and TS EN ISO 15189 standard demand the validation and verification of all tests so as to confirm the proper performation and correct results $(2,3)$.

Detailed analysis are performed to validate the diagnostic tests in medical laboratories. Analysis such as, accuracy, reproducibility, sensitivity, specificity, detection limit are performed and tests are put into practice followed by the valid results $(4,7,8)$. Although all validatition tests were performed by the manufacturers for CE-approved tests, performance of the test should be confirmed prior to the routine use in the laboratories $(3,8)$. The performance written in the kit insert should be confirmed by the laboratory.

Different levels of performance could be observed in different laboratories in all tests including standardized commercial microbiological tests. Test results could be influenced by the diversity of patient group, infrastructure, personal application, specifications of the device. So it should be investigated if the manufacturer's statement fits in the laboratory in the scope of accuracy and precision of the test. Verification should be performed prior to routine use of the tests as well as at the time of any change in the procedure of the tests or any change in the device or the person who is performing the test $(1,9)$.

Control materials used in the verification studies has an important role. Ideally, providing the reference 
Table 1. Results of accuracy test

\begin{tabular}{|l|l|l|}
\hline Samples (DEU) & Our results & Result of the test \\
\hline 3 Positive & 3 Positive & $9 / 9 * 100=100 \%$ \\
3 Low positive & 3 Low positive & \\
3 Negative & 3 Negative &
\end{tabular}

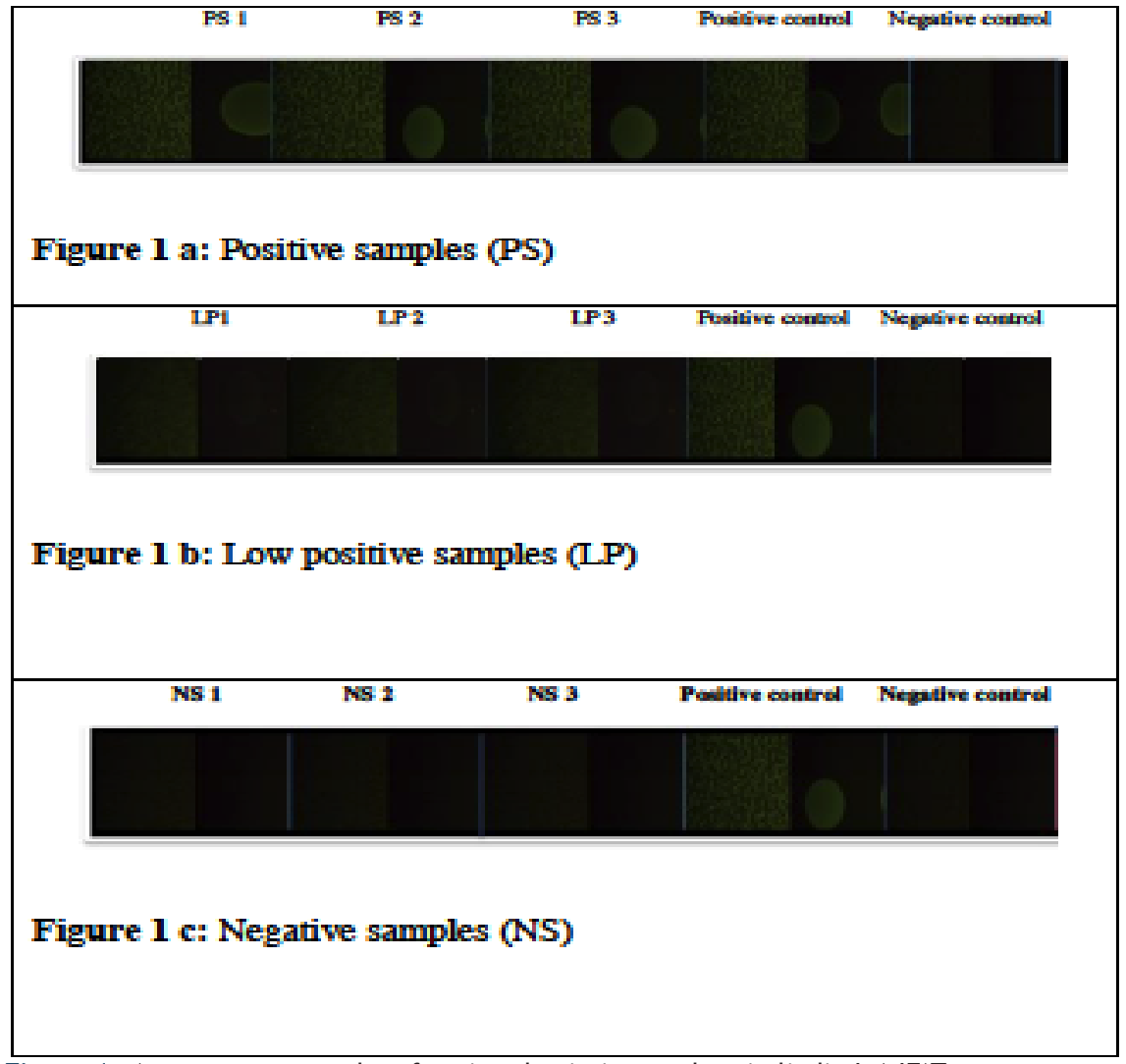

Figure 1. Accuracy test results of anti-endomiysium and anti-gliadin IgA IFAT

Table 2. Results of intra-assay precision test

\begin{tabular}{|c|c|c|}
\hline Samples (DEU) & Our results & Result of the test \\
\hline 1 Positive & 1 Positive & \\
\hline & & $6 / 6 * 100=100 \%$ \\
\hline 1 Low positive & 1 Low positive & \\
\hline
\end{tabular}




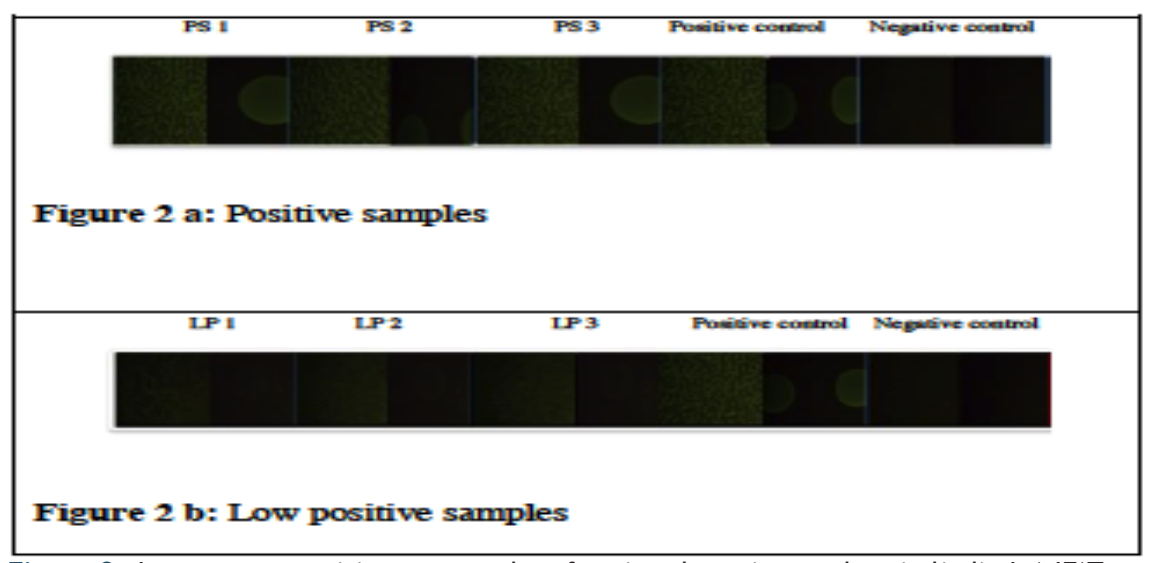

Figure 2. Intra-assay precision test results of anti-endomysium and anti-gliadin IgA IFAT

Table 3. Results of inter-assay precision test

\begin{tabular}{|c|c|c|}
\hline Samples (DEU) & Our results & Result of the test \\
\hline 1 Positive & 1 Positive & \\
\hline & & $6 / 6 * 100=100 \%$ \\
\hline 1 Low positive & 1 Low positive & \\
\hline
\end{tabular}

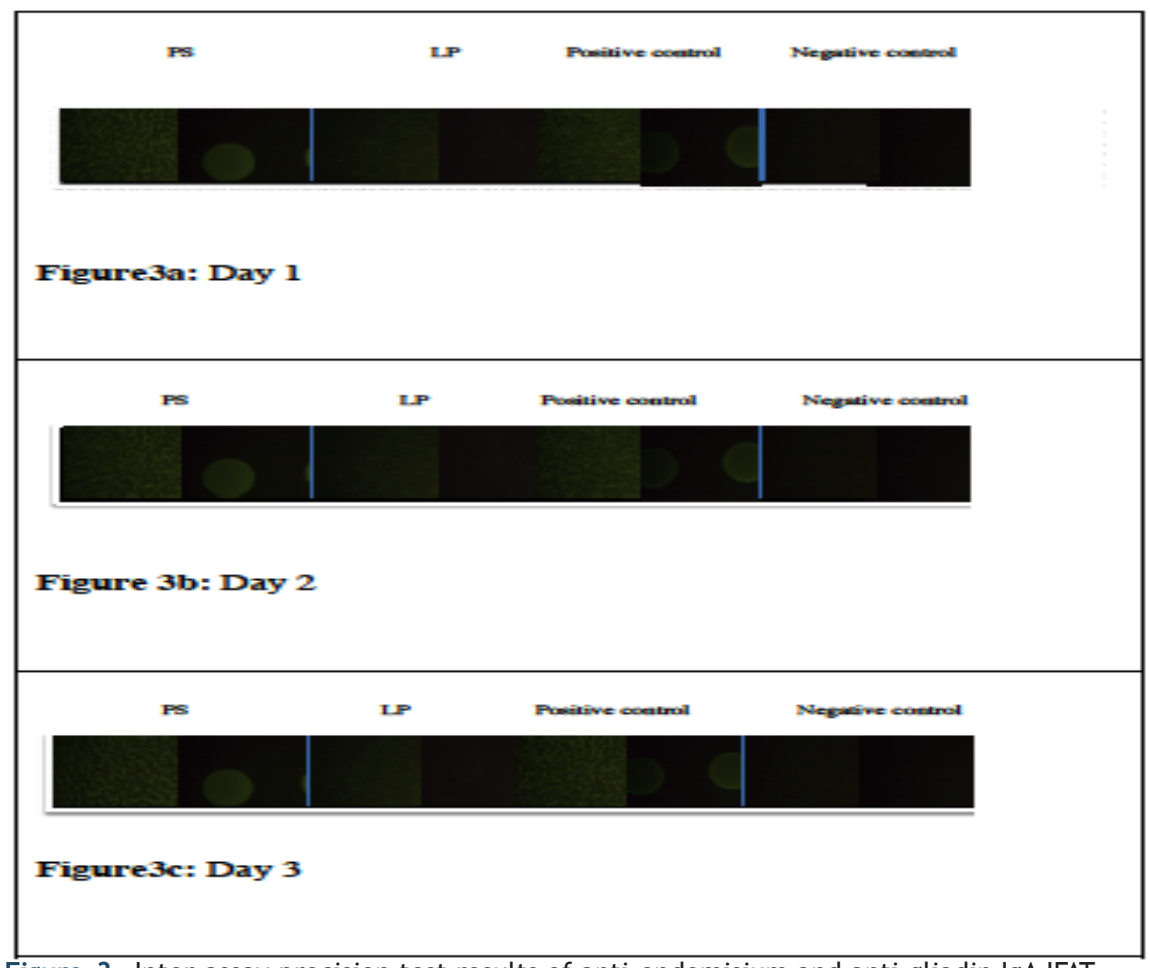

Figure 3. Inter-assay precision test results of anti-endomisium and anti-gliadin IgA IFAT 
Table 4. Results of accuracy test

\begin{tabular}{|l|l|r|}
\hline Samples (DEU) & Our results & Result of the test \\
3 Positive & 3 Positive & $9 / 9 * 100=100 \%$ \\
3 Low positive & 3 Low positive & \\
3 Negative & 3 Negative
\end{tabular}

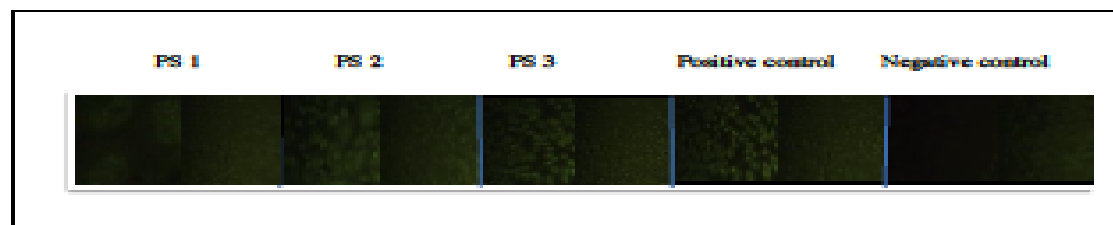

Figure 4 a: Positive samples (PS)

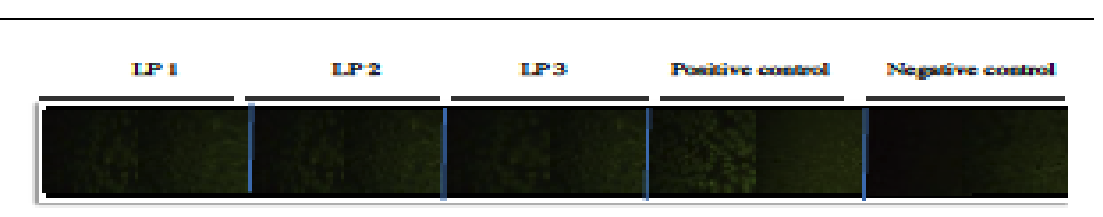

Figure 4 b:Low positive samples (LP)

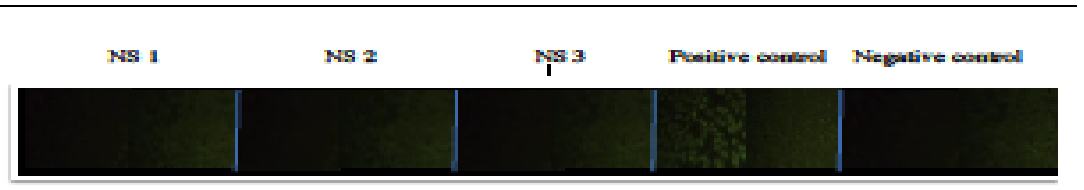

Figure 4 c: Negative samples (NS)

Figure 4. ANA IgG IFAT doğruluk çalıșması

Table 5. Results of intra-assay precision test

\begin{tabular}{l|l|r}
\hline Samples (DEU) & Our results & Result of the test \\
\hline 1 Positive & 1 Positive & $6 / 6 * 100=100 \%$ \\
1 Low positive & 1 Low positive
\end{tabular}




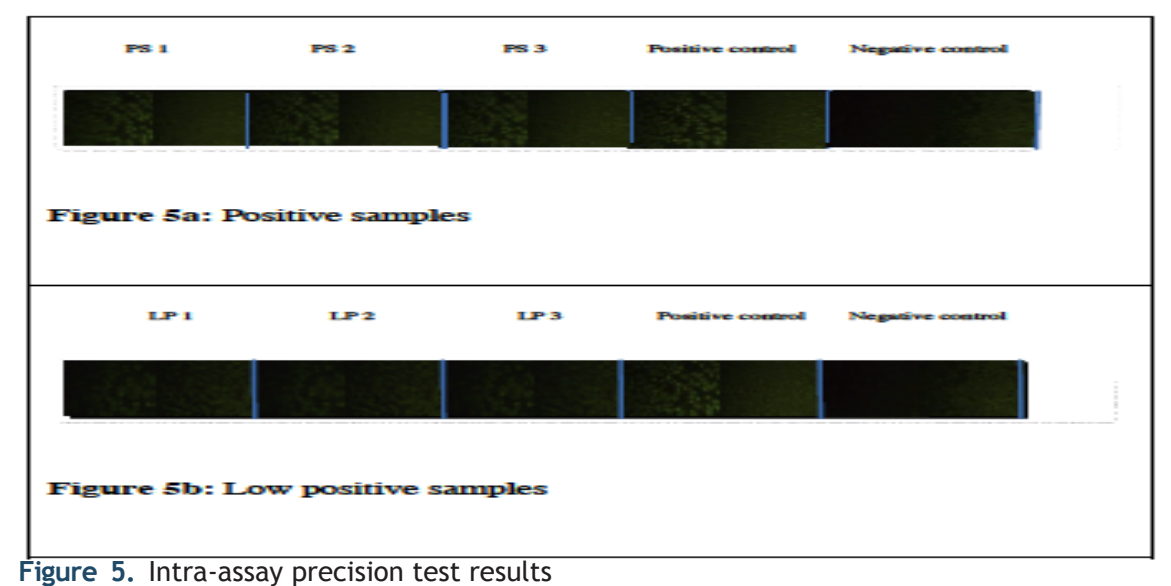

Figure 5. Intra-assay precision test results

Table 6. Results of inter-assay precision test

\begin{tabular}{|c|c|c|}
\hline Samples (DEU) & Our results & Result of the test \\
\hline 1 Positive & 1 Positive & \\
\hline & & $6 / 6 * 100=100 \%$ \\
\hline 1 Low positive & 1 Low positive & \\
\hline
\end{tabular}

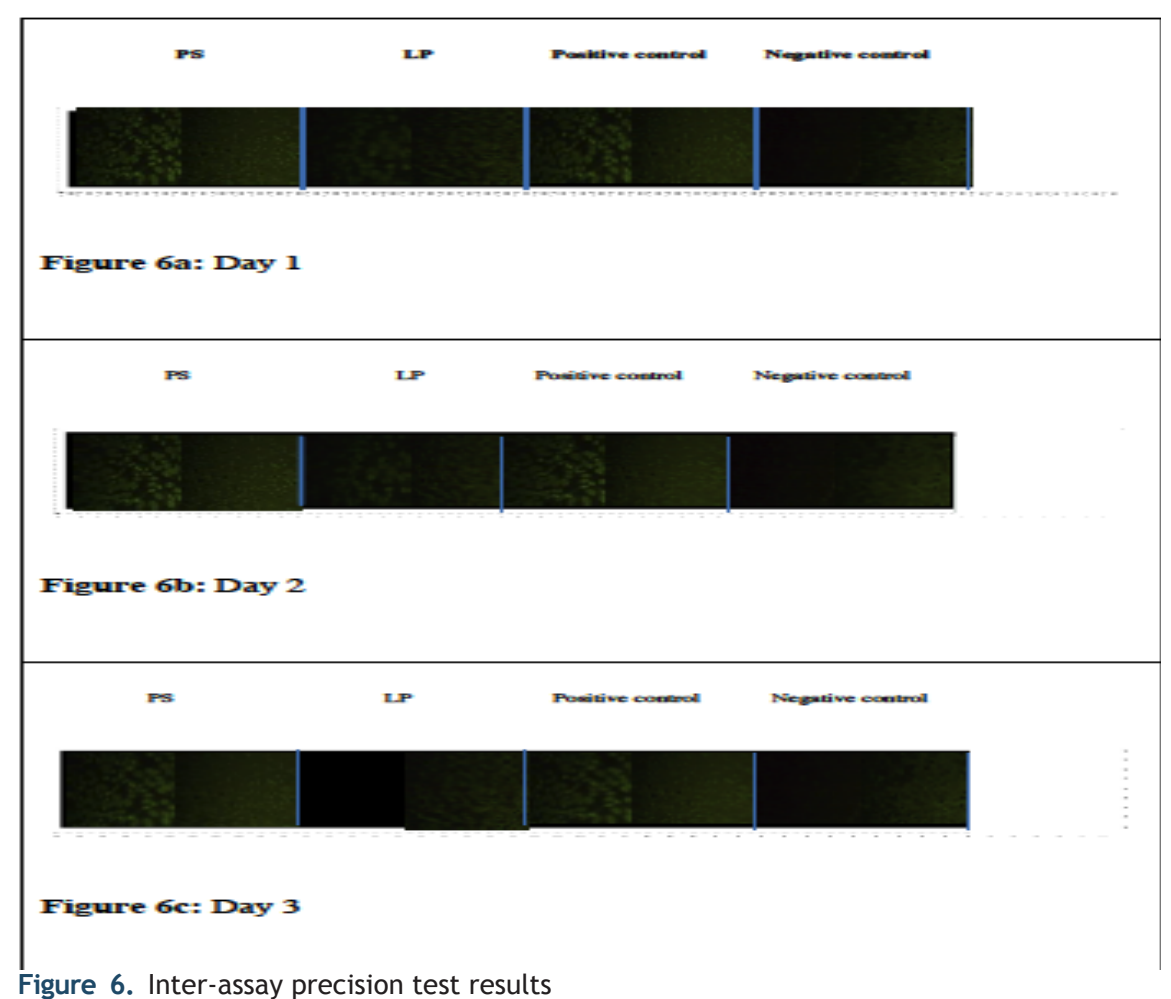

Figure 6. Inter-assay precision test results 
material is mostly recommended. External quality control panels, commercial reference panels and as well as samples of a instutition accrediated for the decided parameter as we used in this study could be used in case of lack of reference material (4). In this study, samples from DEU, Immunology Department, accrediated with TS EN ISO 15189 were used as control material. Among ANA samples sent for IgG IFAT, both ANA negative samples were present along with ANA positive samples with rough granular, nuclear dots and homogen patterns. As different patterns represents different autoimmun diseases, accurate evaluation of the patterns is crucial for the diagnosis of the disease. ANA pattern has a critical importance especially in the discrimination of ANA positive healthy individuals from individuals with autoimmune diseases (10). In a study of Mariz HA (11) et al. the common ANA pattern among healthy subjects was intense, granular and among autoimmune diseases it was homogenous, rough granular and centromer pattern.
The second test that we evaluated was method verification of anti-Gliadin IgA and anti-endomysium IgA that was used for the diagnosis of Celiac disease. While anti-gliadin antibodies (AGA) IgA and IgG mostly used for screening in the diagnosis of Celiac disease, anti-tissue transglutaminaz (dTG) IgA and anti-endomysium (EMA) IgA autoantibodies are used as highly reliable serological tests in the diagnosis and follow-up of the disease (11). In this study, positive, low positive and negative samples of DEU Immunology Department accreditated for the mentioned tests were used for accuracy and precision tests. All results tested in our laboratory were 100\% compatible with the results achieved by DEU.

In conclusion, during preparations for accreditation it is considered that, using samples of an accreditated institution for accuracy and precision testing is a practical way in cases where it is difficult to obtain certified material.

\section{REFERENCES}

1. Berwouts S, Morris MA, Dequeker E. Approaches to quality management and accreditation in a genetic testing laboratory. Eur J Hum Genet 2010; 18(1): 1-19.

2. Silvia Á, Francisco A, Bernabeu A. Procedures for validation of diagnostic methods in clinical laboratory accredited by ISO 15189 . Modern approaches to quality control, Dr. Ahmed Badr Eldin (Ed.), 2011. ISBN: 978-953-307-971-4.

3. Rabenau HF, Kessler HH, Kortenbusch M, Steinhorst A, Raggam RB, Berger A. Verification, validation of diagnostic laboratory tests in clinical virology. J Clin Virol 2007; 40(2): 93-8.

4. Carey NR. Clinical and Laboratory Standards Institute (CLSI). User verification of performance for precision and Trueness; Approved DuidelineSecond Edition. CLSI document EP 15-A2 (ISBN 1-56238-574-7). Wayne, Pennsylvania 19087-1898 USA, 2006.

5. Yılmaz Ö, Karaman M, Ergon MC, Bahar ìH, Yuluğ $\mathrm{N}$. Comparison of indirect immunofluorescence and enzyme immunoassay methods for the determination of antinuclear antibodies. Mikrobiyol Bult 2004; 38(1-2): 85-90.

6. Sener, B, Kaklikkaya N, Ongut G. ACR position statement on ANA testing, February 2009 www. rheumatology.org / publications/ position/ ana position_st mt.asp?aud=mem (Approved by board directors, Aug. 2011).
7. Burd EM. Validation of laboratory-developed molecular assays for infectious diseases. Clin Microbiol Rev 2010; 23(3): 550-576.

8. Clark RB, Lewinski MA, Loeffelholz MJ, Tibbetts RJ. Cumitech 31A: Verification and validation of procedures in the clinical microbiology laboratory. SE Sharp Coordinating ed. ASM Pres Washington DC, 2009.

9. Mattocks CJ, Morris MA, Matthijs G, Swinnen E, Corveleyn A, Dequeker E, Müller C, Pratt V, Wallace A, Eurogentest Validation Group. A standardized framework for the validation and verification of clinical molecular genetic tests. Eur J of Hum Genet 2010; 1-3.

10. Mariz HA, Sato El, Barbosa SH, Rodrigues SH, Dellavance A, Andrade LE. Pattern on the antinuclear antibody-HEp-2 test is a critical parameter for discriminating antinuclear antibodypositive healthy individuals and patients with autoimmune rheumatic diseases. Arthritis Rheum 2011; 63(1): 191-200.

11. Hill ID, Dirks MH, Liptak GS, Colletti RB, Fasano A, Guandalini S et al. Guideline for the Diagnosis and Treatment of Celiac Disease in Children: Recommendations of the North American Society for Pediatric Gastroenterology, Hepatology and Nutrition. J Pediatr Gastroenterol Nutr 2005; 40(1): 1-19. 